$\underline{\text { Review Article }}$

\title{
VITAMIN C AND ITS ROLE IN BODY
}

\author{
RACHIT KUMAR GUPTA ${ }^{a}$ (iD) SHIVANG KUMAR ${ }^{a}$ iD , ABHINAV TRIVEDI ${ }^{*}$ iD ROHAN VERMA $^{a}$ iD YOGESH $^{a}$ \\ aMoradabad Educational Trust Faculty of Pharmacy, Moradabad, UP, India \\ *Email: trivediabhi.1999@gmail.com
}

Received: 18 Oct 2021, Revised and Accepted: 17 Dec 2021

\begin{abstract}
Ascorbic acid or Vitamin $C$ is very important in our body because of its antioxidant property. But the main problem; that vitamin $C$ uses is to maintain the stability as well as its drug distribution system. Vitamin C also plays a protective role in diabetes, cancer, heavy metal toxicity or poisoning, etc. Vitamin C is found in many sources present in nature, including tomatoes, broccoli, etc. Many factors in the body, as well as outside the body, affect the content of vitamin $C$ in the body or sources like the season, climate, and pollution affect the content in fruits and vegetables besides sex, age, pregnancy, lactation, etc. affect the vitamin $\mathrm{C}$ content in the body. It is extensively used in the common cold, wound healing process, cancer, heavy metal poisoning or toxicity, and even in men's fertility. In this article, we focused on the general aspects: its bioavailability, sources, its toxicity and deficiency, and factors affecting vitamin $\mathrm{C}$ level as well as its use in humans. In the last, we conclude, the excess or lack of Vitamin $\mathrm{C}$, both conditions have affected the human body in a significant range. It plays a protective role against many disorders and is required for kids, men, women, and even old-aged patients.
\end{abstract}

Keywords: Vitamin C, Ascorbic acid, Applications, Toxicity, Cancer, Tissue healing, Fertility, Common cold

(C) 2022 The Authors. Published by Innovare Academic Sciences Pvt Ltd. This is an open access article under the CC BY license (https://creativecommons.org/licenses/by/4.0/) DOI: https://dx.doi.org/10.22159/ijpps.2022v14i2.43394. Journal homepage: https://innovareacademics.in/journals/index.php/ijpps.

\section{INTRODUCTION}

Ascorbic acid or Vitamin C is made up of 6 carbons as glucose and hydrophilic [1]. Vitamin C can exist in reduced forms that is ascorbic acid or ascorbate, whereas it can also exist in an oxidized form that is dehydroascorbic acid (DHA), made up by reduction of ascorbic acid [2]. It has some necessary anatomical and catabolism action in human beings, but human beings don't have the L-gulonolactone oxidase enzyme so that's why it is not formed in human beings. Vitamin $C$ is just acquired through edibles or external sources. Scurvy is a disease condition occurring due to the lack of vitamin C and considered via the fragility in tissue, capillary, and poor wound healing as well. But the cases of scurvy are rare in the present time. Ascorbic acid is a prominent element within the food, as well as pharmaceutical fields [3]. Structure of Ascorbic acid in fig. 1.

Vitamin C is known to play its antioxidant properties in a significant range and is also known to play countless functions for maintaining optimal health to protect the human from various diseases $[4,5]$. The deficiency of vitamin C, called hypovitaminosis $\mathrm{C}$, is connected with symptoms like low mood [6]. More serious deficiencies are often related to a variety of clinical aspects [7] and prolonged deficiency even results in scurvy syndrome, a case in which an individual is determined usually for heart problems in public nowadays [8]; if this condition isn't treated within the time then it may lead to death. The high ingestion concentration of Vitamin C in the body in different conditions is a topic of discussion and suggestion values are not common [9].<smiles>O=C1O[C@H]([C@H](O)CO)C(O)=C1O</smiles>

Vitamin $\mathrm{c}$ is a precious component of our body that protects us from diseases. In this article, we mainly describe the general aspects, factors that affect the vitamin $\mathrm{C}$ level in the body, and applications with future perspectives. Through this article, we conclude that even minute deficiency of vitamin $\mathrm{C}$ is associated with a serious condition, whether it is in the form of disease or it may directly affect the population and it is important for all kids, men, women, and old aged patients to keep fit, healthy, improve immunity and heart functions, and skin functions. It is used in cancer, diabetes mellitus, hypertension, sickle cell anemia, etc. as a supplement.

\section{Search criteria}

This review was made after reviewing approx 300 articles from 1940 to 2020, which were found on electronic database systems like PubMed, Science Direct, and Google Scholar by using keywords like vitamin C, vitamin C and their Applications, Pharmacology, and Toxicity of vitamin C, Ascorbic Acid, vitamin C and deficiency, Cancer, etc. After analyzing all articles, few articles were found to be effective for the study about vitamin $\mathrm{C}$. Then, a comparative study is presented in this review to make it more informative and relevant.

\section{Sources of vitamin C}

Vegetables and fruits like citreous fruits, strawberry, tomato, broccoli, Indian gooseberry, turnip, sprouted grains, red peppers, green peppers, and many green veggies are rich in vitamin $\mathrm{C}$ content. Vitamin $C$ is found in animal sources at a very low concentration about; $30-40 \mathrm{mg} / 100 \mathrm{~g}$ whereas, plant sources may have vitamin $\mathrm{C}$ concentration up to $5000 \mathrm{mg} / 100 \mathrm{~g}$. So plants are becoming important sources of vitamin C. It can be absorbed either by passive diffusion in the buccal cavity or by Sodium dependent active Vitamin C transporters in GIT (Gastro-Intestinal Tract) [10,11].

\section{Bioavailability of vitamin C}

The absorption and renal excretion of vitamin $\mathrm{C}$ decide the extent of bioavailability in the body. The main source of ascorbic acid is diet or supplements. The consumption of vitamin C from any dietary source is absorbed either from the small intestine through epithelial cells by SVCT1 (Sodium dependent active Vitamin C transporters-1) or circulates into the capillaries and further in the bloodstream [11, 12]. This circulating amount of ascorbic acid vitamin $C$ is then undergoing a general filtration mechanism in Bowman's capsule form kidney and the ascorbic acid is reabsorbed in PCT (Proximal Convoluted Tubule) [12]. Variance between the filtered and reabsorbed volume of ascorbic acid establishes renal excretion [13]. If the vitamin $C$ is available in a low concentration, it undergoes absorption in the small intestine and undergo excretion [14], whereas if the vitamin $C$ is available in a high concentration, it is regulated via SVCT1 [15] and this decides the absorbed amount form intestine and excretion from the kidney [16]. So this is 
concluded that the level and the bioavailability is regulated by absorption through intestine and excretion through kidney as well.

There are many other reasons that play a major role in reducing bioavailability including alcohol intake, stress, usage of antibiotics, smoking, fever, viral illness, painkiller, heavy metal toxicity, exposure to carbon monoxide or petroleum products, even more. Perhaps, increased consumption of vitamin $C$ is seen in these situations that results in the deficiency of vitamin $\mathrm{C}$. The appliance through which the low vitamin $\mathrm{C}$ serum level occurs in the body is not well cleared yet [17]. Higher ingestion of Vitamin C may cause diarrhoea and GIT disturbance. The other side effects are easily treated by reducing the dosing of ascorbic acid [19].

\section{Factors affecting vitamin c status}

\section{Season and climate}

The most important sources of vitamin $\mathrm{C}$ are fruits and vegetables and are easily available with different concentrations of vitamin $\mathrm{C}$ depending upon the climate as well as season. According to studies from England and China, there is a concentration difference up to 10 $\mu \mathrm{mol} / \mathrm{l}$ of vitamin $\mathrm{C}$ in fruits and vegetables depending on the season, as the highest amount of vitamin C is found in winter as in autumn [20, 21]. According to a China study, the amount of vitamin $C$ found is much higher in winter as compared to spring [22]. This clearly shows the kind and concentration of vitamin C-rich vegetables and fruits that are consumed in winter. This type of condition is observed in different parts of India like in the northern part of India, in which less deficiency is seen in the seasons of winter; but in south India, the high deficiency rate is observed in winter seasons as compared to the northern part [23]. This is likely to show about the altered climatic as well as agricultural conditions throughout the different parts of India. According to the scientist Bates et al. [24], a report shows that change in season with higher consumptions and blood status as compared to the low difference in individuals that have low consumptions and status, this is because of a decreased body area and consumption of the vitamins. Fluctuations in climatic conditions are also responsible for the impact of vitamin C concentration on the populations [25]. This may result in increased dependence on local crops that may drop their vitamin content previous to intake [26].

\section{Pollution}

According to WHO information over $80 \%$ of the population that lived in urban regions are exposed to such air quality levels beyond the WHO limits, with LMICs experiencing the most elevated openings. About 7M unexpected deaths are caused by air pollution across the world every year and this primarily due to the expanded deaths from strokes, coronary disbalances, cellular breakdown in the lungs, and severe respiratory diseases [27]. Air pollution in the environment is likely caused by smoking from burning biomass, and smoking tobacco worldwide. Smoking tobacco is the main one of the causes that decrease the vitamin $C$ status in both non-smoking adults and kids [28, 29, 30]. According to scientists Tribble et al. [29] reports tackled down that amount of the nutrient $\mathrm{C}$ in inactive smokers was lower than the non-exposed non-smokers. Deficiency of vitamin C that is Hypovitaminosis $\mathrm{C}$ was seen in $12 \%$ of inactive smokers but it was not seen in the case of a non-exposed non-smoker.

\section{Sex}

Female tents need a higher amount of vitamin $\mathrm{C}$ than males [31]. The UK males have a lack of vitamin $\mathrm{C}$ than females, as indicated by McCall et al. [32]. This difference of vitamin C content between male and female is because of the high fat-free mass in male [33]. There is also the difference in diet intake between men and women, in which female intake is higher than men [31]. It can be noticed that in pregnancy and lactation conditions, ladies have low amounts of vitamin $C$ because of the hemodilution and proper development of foetus. The doctors from different nations have recommendations for the high dietary intake for male and for pregnant and lactating females, differing according to their body weight [9].

\section{Age}

Few studies have been carried out in individuals matured $>60$ y that have a lower vitamin $\mathrm{C}$ amount than the young age group people in the same country. Many studies have shown that old aged people have a deficiency of vitamin $C$ to a great extent, mainly in males and the aged males have the concentration of vitamin $\mathrm{C}$ concentration as compared to older women [34, 23, 32, 35]. Scientist Schleicher et al. traced a graph in which the curve is U-shaped for vitamin $\mathrm{C}$ amount from age group 6 to $60 \mathrm{y}$ [36]. It is because of the lower weight of kids and old patients, and those who have low intake of vitamin C, are likely to have a deficiency of vitamin C.

\section{Pregnancy and lactation}

Generally, pregnant women have low levels of vitamin C compared to non-pregnant women [37]. It is often possible because of the hemodilution, and active transmission of nutriment, and vitamins through mother to vertebrate [38]. Deficiency of vitamin C in pregnant women may raise the risks of many complications. In that case, supplementation therapy with vitamin C for pregnant women may decrease some complications during pregnancy [39]. Some studies of highly economic countries that include ladies with regular vitamin $C$ levels have not shown any beneficial effect from supplementation [40]. But, in some studies of low-income countries, that include ladies with vitamin C deficiency show potential edges together with a decrease rate of complications in pregnancy [41]. It's significant that the recently discovered epigenetic restrictive undertaking of vitamin $\mathrm{C}$ may have vital roles to play in the development of fetal [42]. A study related to animal models has been shown that parental vitamin $\mathrm{C}$ will regulate desoxyribonucleic acid (DNA) methylation and germline development [43]. The lactating women probably have a lower vitamin $C$ level because the vitamin C is being transferred to the growing baby via breast milk. Several authorities are making improved recommendations in order to increase the needs of pregnant and lactating ladies, with higher than their customary diet endorsements of $+10-20 \mathrm{mg} /$ day for pregnant ladies and $+20-60 \mathrm{mg} /$ day for fresh ladies [9].

\section{Smoking}

Smoking is the main source of oxidative stress and oxidants in the body [44]. Several studies have shown a higher lack of vitamin C in smokers than non-smoker persons. McCall et al. [13] said that smokers are more likely to have a deficiency than non-smokers over 7 times and Wrieden et al. [16] showed the level of deficiency in male and female smokers over 2 to 3 times. Due to the low diet intake of vitamin $\mathrm{C}$ and higher intake of fat make smokers at the higher risk of vitamin $C$ deficiency. Generally, smokers need more vitamin $\mathrm{C}$ as related to non-smokers due to the vitamin C deficiency $[45,46]$. A study by Kallner et al. [47] which shows an increase in vitamin $C$ turnover in smokers by more than $35-40 \%$ compared with non-smokers. Several international regulatory bodies have taken into account the increased needs of smokers by offering additional recommendations ranging from 20 to 80 $\mathrm{mg} /$ day for adults [9]. However, this additional intake may not be enough to compensate for the increased demand of smokers. Moreover, in some countries, there is still an upward tendency in smoking rates, which may affect the vitamin $\mathrm{C}$ level and increase the need for vitamin C [27].

\section{Disease state}

Various disease states can affect the vitamin C level in the body like inflammation and increased oxidative stress. Various diseases are associated with a lack of vitamin C; such as cardiovascular disease, congestive heart failure, metabolic disorders, and chronic inflammatory conditions etc. $[5,48]$. Some acute infectious disease states can result in inflammation and ultimately result in decreased plasma as well as vitamin C concentrations, whereas chronic infections like Human infection virus (HIV), Helicobacter pylori and tuberculosis, are common in many lower-middle-income region [49, 50]. An increased demand vitamin $C$ is needed in infectious diseases and as the severity of the infection increases, the demand of vitamin $\mathrm{C}$ also increases so as to achieve the normal level [51]. Decrease vitamin $C$ level is also seen in the global coronavirus pandemic (SARSCoV2) [52]. People who have a negligible level of vitamin C have an increased possibility of vitamin C deficiency and as those are deficient then higher intake of vitamin is needed to raise the deficient state $[52,53]$. 
Table 1: A summary of above discussed factors affecting vitamin $\mathrm{C}$ status is given below

\begin{tabular}{ll}
\hline Factors & Their affect \\
\hline Season and climate & May increase or decrease the Vitamin C content in vegetables and fruits [20, 21] \\
Pollution & Due to air pollution, it may affect the Vitamin C content [28, 29] \\
Sex & Female tents need a higher amount of vitamin C than males [31]. \\
Age & matured $>60$ y have a lower vitamin C amount than the young age group people [34, 35] \\
Pregnancy and lactation & pregnant women and lactating women have low levels of vitamin C [37] \\
Smoking & Smokers are likely to have Vitamin C deficiency [13] \\
Disease state & Disease states like inflammation and increased oxidative stress cause the low Vitamin C levels [5, 48]. \\
\hline
\end{tabular}

\section{Vitamin $\mathrm{C}$ in human beings}

Vitamin C plays a vital role in human beings for growth as well as for proper health. Either excess of vitamin C or deficiency of vitamin C may lead to disturbance in human health. Some of the important benefits have been discussed below, shown in fig. 2 below:

\section{Vitamin $C$ in common cold}

Being helpful for the treatment of scurvy, it is also helpful in the management of common colds. This concept was described by Paul and suggested that 1 to 3 gram of dose is effectively used for treatment [54]. Vitamin C plays an important role in the common cold. It's a controversial phase and studies are continuing in this phase [55]. Many studies show that the change in dose amount doesn't show any effect in prophylactic response, but it mainly affects the symptoms of cold in the manner of decreasing the severity and duration as well. According to many studies, the 1 gram/day of vitamin $\mathrm{C}$ dose isn't effective in the management of the common cold during the winter seasons [56]. Immunodeficiency is the common thing in common colds. Many discussions are continuing about vitamin $\mathrm{C}$ in boosting immunity in rhinitis cases. The ascorbic acid plays an important role in immunity and stimulates the proliferation of T-cells in respect to infection. T-cells are effective in the treatment of infected organs via either increasing the production of cytokines or via promoting the B-cells to produce immunoglobulins or antibodies to monitor the infective reaction. The ascorbic acid does this work by blocking the pathway that results in apoptosis of T-cells, thus maintaining them. This is the proposed mechanism behind the enhancement of the immune system in the case of rhinitis when vitamin $C$ is administered $[57,58]$.

\section{Vitamin $\mathrm{c}$ in tissue healing}

It is a process that needs collagen to be synthesized and accumulated and further their crosslinks with fibers to provide sufficient strength to damaged organs. In the terms of collagen synthesis, ascorbic acid is beneficial for the wound healing process as indicated by several studies. As per the new study, the wound healing process was achieved by giving maximum tensile strength to scar tissue of guinea pigs after the administration of vitamin $C$ [59]. Ascorbic acid or vitamin $C$ is required in a huge amount for postoperative patients as they have fast utilization in the body to synthesize collagen for the wound healing process at the site of injury. Hence, the recommended dose for post-operative patients is $500 \mathrm{mg}-1$ gram in order to provide a sufficient supply of ascorbic acid for the wound healing process [60]. Jagetia et al. suggested that the ascorbic acid in pre-treatment during the injury and trauma conditions was helpful for promoting the wound healing process and proposed a strategy regarding the vitamin $C$ for accelerating the wound healing process in these cases [61].

\section{Vitamin c infertility}

Vitamin $C$ is used in male infertility in the case of non-specific seminal infections [62]. But, the exact action of ascorbic acid remains unclear yet in the case of male fertility. A scientist named Chinoy said that vitamin $C$ is an important component for promoting integrity in the structural and functional basis as well as in the reproductive system. In guinea pigs, it showed some degenerative changes in testes, as well as vas deferens [63].

Antioxidant is the main property of ascorbic acid and this property plays a major role up to $65 \%$ in men infertility [64]. There is a concentration difference of ascorbic acid between plasma concentrations and the seminal plasma up to 10 times more and this concentration difference was also found in the seminal plasma of fertile and the seminal plasma of infertile men $[65,66]$. Deficiency of ascorbic acid may cause increased oxidative damage in organs caused by ROS (Reactive Oxygen Species). The 25\% to $45 \%$ concentration of ROS was found in the semen of infertile men [67]. As per the studies, the supplements of vitamins $C$ are beneficial in many terms that lead to affecting the fertility of men like it reduces the ROS concentration, increases sperm quality [68], decreases sperm DNA oxidation as well as decreases sperm membrane lipid peroxidation [69]. The supplements of vitamin $C$ as antioxidants are helpful in enhancing sperm quality in a dose-dependent manner [68]. Supplementation of Vitamin C also has an effective role in women infertile in the terms of increasing the levels of progesterone in the case of luteal phase defect [70].

\section{Vitamin $C$ in cancer}

Vitamin C has preventive properties in the case of carcinoma or cancer and this concept was first described in 1949 by Cameron et al. He described that vitamin $\mathrm{C}$ at a high dose is helpful in improving the life of patients with fatal cancer [71]. But, the primary documented study was done by Pauling and Cameron in 1970 in which they administered vitamin $\mathrm{C}$ to cancer patients. They administered 10 grams of vitamin $C$ daily to patients of cancer in a group of 100 people and compared their results with the group of 1000 people who are suffering from cancer and are treated with only standard therapy. The compared results has been ascertained that $10.3 \%$ patients who were taking vitamin $C$ exist or survived but all the patients who were taking standard therapy died [72]. Higher ingestion of Vitamin C is related with a low number of risks for nonhormonal [73] as well as hormonal cancers like breast, rectum, esophagus, stomach, pancreas and oral cavity cancers [74, 75].

There are several mechanisms which follow the involvement of vitamin $C$ in the therapy are as follows: stimulates the collagen formation, prevent viruses that involved in cancer, enhances wound healing process in cancer patients, prevents free radical formation and their damage to tissues, enhancement of vitamin C deficiency, prevent spread of cancer by suppressing enzymes, improves the immune system, reducing toxicity of drugs used in chemotherapy [73]. The role of vitamin $\mathrm{C}$ in cancer management has been described by many studies in two ways: that, at the higher concentration of vitamin $\mathrm{C}$, cancer cells do not develop or lead to shrinkage of cancer cells $[76,77]$. The administration of vitamin $C$ via intravenous route may increase the effectiveness up to 70 -fold as compared to oral route administration [78]. Most of the studies may conclude that vitamin $\mathrm{C}$ gives the beneficial result at a higher dose in the development of tumours as well as their mechanism of action also contributes to the anti-cancer effect [79].

\section{Vitamin $\mathrm{c}$ in heavy metal toxicity}

Heavy metals may result in dangerous toxicity in human beings. These metals toxicity either via redox cycling, for example like chromium, iron, vanadium and copper etc. or via making of Reactive Oxygen Species [ROS] in shape of superoxide ion, example like lead, mercury, nickel etc. and after that disturbed calcium level, damage in DNA, and lipid peroxidation occur as a part of homeostasis [80].

The vitamin $C$ is helpful in the lead poisoning cases and it was also proved by various studies. The lead toxicity is extensively harmful for the brain, kidneys, testes, and liver [81]. Arsenic poisoning shows its toxic effect via oxidative stress and lipid peroxidation as well. If 
excess amounts of the arsenic is present in water, then it leads to molecular ailments [82]. As per a study, the arsenic may cause lipid peroxidation in excess amount in rats during the lactation and maturation phase and this has retreated with the supplements of vitamin C, E and Zn [83]. Cadmium also comes under the toxic metal category and is mainly found in industrial area. Vitamin $\mathrm{C}$ provides protection in cadmium poisoning in rats when its brain and lungs are affected [84]. Vitamin C is also recognised to relapse the haematological changes in cadmium poisoning and mercury poisoning [85]. Hence we can say that Vitamin C or Ascorbic acid have protective properties in heavy metal toxicity.

\section{Vitamin $\mathrm{c}$ in diabetes}

Diabetes creates a serious condition in the future as it can affect 360 million people [86]. Many Symptoms like deteriorated, over the long term damage and abortion of many organs are happening in diabetic patients. Kidney, blood vessels, nerves, eyes and heart are mainly affected due to the high level of glucose in the human body [87]. Oxidative stress [69] is mainly induced by ROS [19] in Hyperglycaemia. The increased production of ROS is seen in both types of diabetes that lead to oxidative stress with onset of diabetes, this statement is proved by several experiments and studies as well [88]. Vitamin $C$ is helpful in reducing the many developing risks of diabetes. The plasma level of Vitamin C, and ingestion of veggies, fruits connected with risks of Diabetes Mellitus of type 2, this statement is recognized by the study of Norfolk Prospective [89]. In the diabetic cases, vitamin $\mathrm{C}$ and $\mathrm{E}$ are reduced trauma in tissue as well as in blood. MOA (Mode of action) behind this is monitoring the antioxidant action and modifying lipid content [69]. Many microvascular and macrovascular complications have been connected with diabetes. Hyperglycaemia is liable for Reactive Oxygen Species [ROS], which occur in diabetic cases that result in endothelial impairment [90]. Hence, vitamin C is capable of blocking the impaired hyperglycaemic dysfunction in diabetic cases [91]. Neuropathy is also one of the complications among diabetic patients. There are many reasons that show the significant lowering vitamin C level in patients of diabetes and polyneuropathy [92]. In the dieabitic patient, the importance of ascorbic acid and other antioxidants is described by many authors [93].

\section{Vitamin c toxicity}

People, who suffer from G6PD deficiency (glucose-6-phosphate dehydrogenase) which is treated by ascorbate supplements in higher amounts, are at most probably chances of hemolysis. According to a report, a 32 y old patient from Nigeria got a supplement of 40 grams of ascorbic acid thrice in a week for about 1 mo, while taking vitamin $C$ every day. When this dose of ascorbic acid increased to 80 grams, acute hemolysis occurred to that patient [94].

There are a few other examples of vitamin C toxicity $(95,96,97)$. The widespread use of ascorbic acid in supplements and food additives make the surety to use ascorbic acid. The recommended average dose of vitamin $\mathrm{C}$ in American people is not less than three times in a day at $180 \mathrm{mg} /$ day. This recommended dose is based on the pharmacokinetic studies of vitamin C. More than $80 \%$ of the dose is absorbed in the body after the administration of $180 \mathrm{mg} /$ day dose. The absorptive capacity of the dose in the intestine seems to be achieved by oral intake of $3 \mathrm{~g} /$ day of ascorbic acid (this capacity is indicated by pharmacokinetic studies). The excessive ascorbate absorption is eliminated by the kidney but avoids increasing Vitamin $\mathrm{C}$ level in the tissue.

An average excretion of oxalate is $20-30 \mathrm{mg} /$ day. That is half of oxalate comes from vitamin $\mathrm{C}$ metabolism. If a person is taking 5 grams of ascorbic acid daily, it is observed that it faces an average increase of $14.8 \mathrm{mg}$ in urinary excretion of oxalate [98]. Thus, we can say that higher intake of ascorbic acid poses a possibility of calcium oxalate stone formation in mostly healthy patients eliminating those people who are likely to have kidney stones [99, 100]. Many researchers assumed that people with kidney stones have unusual metabolism of ascorbic acid and/or unusual absorption of oxalate ions. It is recommended that people having renal failure or kidney stone shouldn't take vitamin C at high dose [99-102].
People who are getting hemodialysis and/or ambulatory peritoneal dialysis are likely to have low vitamin $\mathrm{C}$ status as compared to healthy patients. For enhancing the vitamin $\mathrm{C}$ level, ascorbic acid supplements can be helpful. A normal dose of ascorbic acid supplement ( $50 \mathrm{mg} /$ day) may be helpful in restoration of normal vitamin C levels without causing kidney stones that is without increasing plasma oxalate concentration. But a 500 milligram per day dose of ascorbic acid supplementation up to $3 \mathrm{w}$ may result in increased levels of plasma oxalate [103]. vitamin C toxicity is also associated with other effects like hyperuricemia, systemic regulation, vitamin B12 deficiency but it seems rare [95-97].

\section{CONCLUSION}

Ascorbic acid or vitamin $\mathrm{C}$ has been extensively studied by many scientists as well as its use has also been increased in recent times. It is a resourceful molecule that is used in many fields of pharma and science. Since, many studies show the effective role in men's infertility, cancer treatment, and diabetes and even in neurodegenerative disorders. Ascorbic acid is extremely used to convey the many medicinal agents in the body for promoting the healthy body. But its stability is a main factor that resists its use. The optimum intake of supplements is advantageous to health since its excess can cause hypervitaminosis $\mathrm{C}$ and its deficiency may result in scurvy. It is very beneficial for heart, skin health, as well as immunity in the covid-19 era. It is used mainly for antioxidant properties that reduce the reactive oxygen species in the body that are generated by many disease states like infertility, heavy metal toxicity, diabetes, etc. Its toxicity may be connected with kidney stones, vitamin B12 deficiency, and systemic regulations. In the last, we concluded, vitamin $\mathrm{C}$ has a vital part in keeping human health but it needs more study that shows its beneficial as well toxic effects and come up with new results as the present era of immunity is continuously changing.

\section{CONSENT FOR PUBLICATION}

Not applicable.

\section{ACKNOWLEDGEMENT}

Moradabad Educational Trust, Faculty of Pharmacy, Moradabad, UP, India.

\section{FUNDING}

None

\section{AUTHORS CONTRIBUTIONS}

All the authors have contributed equally.

\section{CONFLICT OF INTERESTS}

The authors declare no conflict of interest.

\section{REFERENCES}

1. Telang PS. Vitamin C in dermatology. Indian Dermatol Online J. 2013 Apr 17;4(2):143-6. doi: 10.4103/2229-5178.110593, PMID 23741676.

2. Kocot J, Luchowska Kocot D, Kiełczykowska M, Musik I, Kurzepa J. Does vitamin C influence neurodegenerative diseases and psychiatric disorders? Nutrients. 2017 Jun 27;9(7):659. doi: 10.3390/nu9070659, PMID 28654017.

3. Sunil Kumar BVS, Singh S, Verma R. Anticancer potential of dietary vitamin D and ascorbic acid: a review. Crit Rev Food Sci Nutr. 2017 Aug 13;57(12):2623-35. doi: 10.1080/10408398.2015.1064086, PMID 26479551.

4. Carr A, Frei B. Does vitamin C act as a pro-oxidant under physiological conditions? FASEB J. 1999 Jun;13(9):1007-24. doi: 10.1096/fasebj.13.9.1007, PMID 10336883.

5. Carr AC, Frei B. Toward a new recommended dietary allowance for vitamin $\mathrm{C}$ based on antioxidant and health effects in humans. Am J Clin Nutr. 1999 Jun;69(6):1086-107. doi: 10.1093/ajcn/69.6.1086, PMID 10357726.

6. Levine M, Conry Cantilena C, Wang Y, Welch RW, Washko PW, Dhariwal KR, Park JB, Lazarev A, Graumlich JF, King J, Cantilena LR. Vitamin $C$ pharmacokinetics in healthy volunteers: evidence for a recommended dietary allowance. Proc Natl Acad 
Sci USA. $1996 \quad$ Apr 16;93(8):3704-9. doi: 10.1073/pnas.93.8.3704, PMID 8623000.

7. Deirawan H, Fakhoury JW, Zarka M, Bluth MH, Moossavi M. Revisiting the pathobiology of scurvy: a review of the literature in the context of a challenging case. Int J Dermatol. 2020 Dec;59(12):1450-7. doi: 10.1111/ijd.14832, PMID 32154584.

8. Ceglie G, Macchiarulo G, Marchili MR, Marchesi A, Rotondi Aufiero L, Di Camillo CD, Villani A. Scurvy: still a threat in the well-fed first world? Arch Dis Child. 2019 Apr;104(4):381-3. doi: 10.1136/archdischild-2018-315496, PMID 30087152.

9. Carr AC, Lykkesfeldt J. Discrepancies in global vitamin C recommendations: a review of RDA criteria and underlying health perspectives. Crit Rev Food Sci Nutr. 2021;61(5):742-55. doi: 10.1080/10408398.2020.1744513, PMID 32223303.

10. Kumar A, Saini RV, Saini AK. Neuroprotective role of ascorbic acid: anti oxidant and non-antioxidant functions. Asian J Pharm Clin Res. 2018;11(10):30-3. doi: 10.22159/ajpcr.2018.v11i10.27318.

11. Malo C, Wilson JX. Glucose modulates vitamin C transport in adult human small intestinal brush border membrane vesicles. J Nutr. 2000 Jan;130(1):63-9. doi: 10.1093/jn/130.1.63, PMID 10613768.

12. Takanaga $H$, Mackenzie B, Hediger MA. Sodium-dependent ascorbic acid transporter family SLC23. Pflugers Arch. 2004 Feb;447(5):677-82. doi: 10.1007/s00424-003-1104-1, PMID 12845532 .

13. Friedman GJ, Sherry S, Ralli EP. The mechanism of the excretion of vitamin c by the human kidney at low and normal plasma levels of ascorbic acid. J Clin Invest. 1940 Sep;19(5):685-9. doi: 10.1172/JCI101171, PMID 16694785.

14. Nelson EW, Lane H, Fabri PJ, Scott B. Demonstration of saturation kinetics in the intestinal absorption of vitamin $\mathrm{C}$ in man and the guinea pig. J Clin Pharmacol. 1978 Jul;18(7):32535. doi: 10.1002/j.1552-4604.1978.tb01601.x, PMID 209065.

15. MacDonald L, Thumser AE, Sharp P. Decreased expression of the vitamin C transporter SVCT1 by ascorbic acid in a human intestinal epithelial cell line. Br J Nutr. 2002 Feb;87(2):97-100. doi: 10.1079/BJN2001492, PMID 11895172.

16. Wilson JX. Regulation of vitamin C transport. Annu Rev Nutr. 2005;25:105-25.

10.1146/annurev.nutr.25.050304.092647, PMID 16011461.

17. Kallner A, Hartmann D, Hornig D. Steady-state turnover and body pool of ascorbic acid in man. Am J Clin Nutr. 1979 Mar;32(3):530-9. doi: 10.1093/ajcn/32.3.530, PMID 420145.

18. Anderson D, Phillips BJ, Yu TW, Edwards AJ, Ayesh R, Butterworth KR. The effects of vitamin $C$ supplementation on biomarkers of oxygen radical generated damage in human volunteers with "low" or "high" cholesterol levels. Environ Mol Mutagen. 1997;30(2):161-74. doi: 10.1002/(SICI)10982280(1997)30:2<161::AID-EM9>3.0.C0;2-Q, PMID 9329641.

19. Johnston CS. Biomarkers for establishing a tolerable upper intake level for vitamin C. Nutr Rev. 1999 Mar;57(3):71-7. doi: 10.1111/j.1753-4887.1999.tb06926.x, PMID 10101920.

20. Ness AR, Cappuccio FP, Atkinson RW, Khaw KT, Cook DG. Plasma vitamin C levels in men and women from different ethnic backgrounds living in England. Int J Epidemiol. 1999 Jun;28(3):450-5. doi: 10.1093/ije/28.3.450, PMID 10405847.

21. Frankenfeld CL, Lampe JW, Shannon J, Gao DL, Li W, Ray RM, Chen C, King IB, Thomas DB. Fruit and vegetable intakes in relation to plasma nutrient concentrations in women in Shanghai, China. Public Health Nutr. 2012 Jan;15(1):167-75. doi: 10.1017/S1368980011001029, PMID 21729475.

22. Lam TK, Freedman ND, Fan JH, Qiao YL, Dawsey SM, Taylor PR, Abnet CC. Prediagnostic plasma vitamin $\mathrm{C}$ and risk of gastric adenocarcinoma and esophageal squamous cell carcinoma in a Chinese population. Am J Clin Nutr. 2013 Nov;98(5):1289-97. doi: 10.3945/ajcn.113.061267, PMID 24025629.

23. Ravindran RD, Vashist P, Gupta SK, Young IS, Maraini G, Camparini M, Jayanthi R, John N, Fitzpatrick KE, Chakravarthy $\mathrm{U}$. Prevalence and risk factors for vitamin C deficiency in the north and south India: A two-center population-based study in people aged $60 \mathrm{y}$ and over. PLoS One. 2011;6(12):e28588.

24. Bates CJ, Rutishauser IH, Black AE, Paul AA, Mandal AR, Patnaik BK. Long-term vitamin status and dietary intake of healthy elderly subjects. 2. Vitamin C. Br J Nutr. 1979 Jul;42(1):43-56. doi: 10.1079/bjn19790088, PMID 486393.
25. Cheung E, Mutahar R, Assefa F, Ververs MT, Nasiri SM, Borrel A, Salama P. An epidemic of scurvy in Afghanistan: assessment and response. Food Nutr Bull. 2003 Sep;24(3):247-55. doi: $10.1177 / 156482650302400302$, PMID 14564929.

26. Montagnac JA, Davis CR, Tanumihardjo SA. Nutritional value of cassava for use as a staple food and recent advances for improvement. Compr Rev Food Sci Food Saf. 2009 Jun 8;8(3):18194. doi: 10.1111/j.1541-4337.2009.00077.x, PMID 33467798.

27. Rahman M, Islam SN. Effect of serum antioxidants (vitamin E, C and A) in Lung cancer patients. Int J Pharm Pharm Sci. 2014 Jul;6(7):578-80.

28. Chiplonkar SA, Agte VV, Mengale SS, Tarwadi KV. Are lifestyle factors good predictors of retinol and vitamin C deficiency in apparently healthy adults? Eur J Clin Nutr. 2002 Feb;56(2):96104. doi: 10.1038/sj.ejcn.1601291, PMID 11857042.

29. Tribble DL, Giuliano LJ, Fortmann SP. Reduced plasma ascorbic acid concentrations in nonsmokers regularly exposed to environmental tobacco smoke. Am J Clin Nutr. 1993 Dec;58(6):886-90. doi: 10.1093/ajcn/58.6.886, PMID 8249873.

30. Preston AM, Rodriguez C, Rivera CE, Sahai H. Influence of environmental tobacco smoke on vitamin C status in children. Am J Clin Nutr. 2003 Jan;77(1):167-72. doi: 10.1093/ajcn/77.1.167, PMID 12499337.

31. Rowe S, Carr AC. Global vitamin c status and prevalence of deficiency: a cause for concern? Nutrients. 2020;12(7). doi: 10.3390/nu12072008. PMID 32640674.

32. McCall SJ, Clark AB, Luben RN, Wareham NJ, Khaw KT, Myint PK Plasma vitamin C levels: risk factors for deficiency and association with self-reported functional health in the prospective European investigation into cancer-norfolk. Nutrients. 2019 Jul;11(7):1552. doi: 10.3390/nu11071552, PMID 31324013.

33. Jungert $A$, Neuhäuser Berthold $M$. The lower vitamin C plasma concentrations in elderly men compared with elderly women can partly be attributed to a volumetric dilution effect due to differences in fat-free mass. Br J Nutr. 2015 Mar;113(5):85964. doi: 10.1017/S0007114515000240, PMID 25735881.

34. Wrieden WL, Hannah MK, Bolton Smith C, Tavendale R, Morrison C, Tunstall-Pedoe H. Plasma vitamin C and food choice in the third Glasgow Monica population survey. J Epidemiol Community Health. 2000 May;54(5):355-60. doi: 10.1136/jech.54.5.355, PMID 10814656.

35. Birlouez Aragon I, Delcourt C, Tessier F, Papoz L, POLA Study Group. Pathologies oculaires liees a l'Age. Associations of age, smoking habits and diabetes with plasma vitamin C of elderly of the POLA study. Int J Vitam Nutr Res. 2001 Jan;71(1):53-9. doi: 10.1024/0300-9831.71.1.53, PMID 11276923.

36. Schleicher RL, Carroll MD, Ford ES, Lacher DA. Serum vitamin C and the prevalence of vitamin C deficiency in the United States: 2003-2004 National Health and Nutrition Examination Survey (NHANES). Am J Clin Nutr. 2009 Nov;90(5):1252-63. doi: 10.3945/ajcn.2008.27016, PMID 19675106.

37. Kiondo P, Wamuyu Maina G, Wandabwa J, Bimenya GS, Tumwesigye NM, Okong $P$. The effects of vitamin C supplementation on pre-eclampsia in Mulago Hospital, Kampala, Uganda: a randomized placebo-controlled clinical trial. BMC Pregnancy Childbirth. 2014 Aug 21;14:283. doi: 10.1186/1471-2393-14-283, PMID 25142305.

38. Juhl B, Lauszus FF, Lykkesfeldt J. Poor vitamin c status late in pregnancy is associated with increased risk of complications in type 1 diabetic women: a cross-sectional study. Nutrients. 2017 Feb 23;9(3):186. doi: 10.3390/nu9030186.

39. Rumbold A, Ota E, Nagata C, Shahrook S, Crowther CA. Vitamin C supplementation in pregnancy. Cochrane Database Syst Rev. 2015 Sep 29;9(9):CD004072. doi: 10.1002/14651858.CD004072.pub3, PMID 26415762.

40. Lykkesfeldt J, Poulsen HE. Is vitamin C supplementation beneficial? Lessons learned from randomized controlled trials. $\mathrm{Br} J$ Nutr. 2010 May;103(9):1251-9. doi: 10.1017/S0007114509993229, PMID 20003627.

41. Ugwa EA. Vitamin C supplementation in pregnancy: a review of current literature. Niger J Basic Clin Sci. 2015 May 8;12(1):1-5. doi: 10.4103/0331-8540.156660.

42. Camarena V, Wang G. The epigenetic role of vitamin $C$ in health and disease. Cell Mol Life Sci. 2016 Apr;73(8):1645-58. doi: 10.1007/s00018-016-2145-x, PMID 26846695. 
43. DiTroia SP, Percharde M, Guerquin MJ, Wall E, Collignon E, Ebata KT, Mesh K, Mahesula S, Agathocleous M, Laird DJ, Livera G, Ramalho Santos M. Maternal vitamin C regulates reprogramming of DNA methylation and germline development. Nature. 2019 Sep;573(7773):271-5. doi: 10.1038/s41586-019-1536-1, PMID 31485074.

44. Lykkesfeldt J, Viscovich $M$, Poulsen HE. Plasma malondialdehyde is induced by smoking: A study with balanced antioxidant profiles. Br J Nutr. 2004 Aug;92(2):203-6. doi: 10.1079/BJN20041191, PMID 15333149.

45. Marangon K, Herbeth B, Lecomte E, Paul-Dauphin A, Grolier P, Chancerelle Y, Artur Y, Siest G. Diet, antioxidant status, and smoking habits in French men. Am J Clin Nutr. 1998 Feb;67(2):231-9. doi: 10.1093/ajcn/67.2.231, PMID 9459370.

46. Schectman G, Byrd JC, Gruchow HW. The influence of smoking on vitamin C status in adults. Am J Public Health. 1989 Feb;79(2):158-62. doi: 10.2105/ajph.79.2.158, PMID 2913833.

47. Kallner AB, Hartmann D, Hornig DH. On the requirements of ascorbic acid in man: steady-state turnover and body pool in smokers. Am J Clin Nutr. 1981 Jul;34(7):1347-55. doi: 10.1093/ajcn/34.7.1347, PMID 7258125.

48. McGregor GP, Biesalski HK. Rationale and impact of vitamin C in clinical nutrition. Curr Opin Clin Nutr Metab Care. 2006 Nov;9(6):697-703. 10.1097/01.mco.0000247478.79779.8f, PMID 17053422.

49. Carr AC. Vitamin C in pneumonia and sepsis. In: Chen Q, Vissers $M$, editors. Vitamin C: new biochemical and functional insights: oxidative stress and disease. Boca Raton, FL: CRC Press Press/Taylor \& Francis; 2020. p. 115-35.

50. Hemilä H. Vitamin C and infections. Nutrients. 2017 Apr;9(4):339. doi: 10.3390/nu9040339, PMID 28353648.

51. Carr AC, Spencer E, Dixon L, Chambers ST. Patients with community-acquired pneumonia exhibit depleted vitamin C status and elevated oxidative stress. Nutrients. 2020 May;12(5):1318. doi: 10.3390/nu12051318, PMID 32384616.

52. Block G, Mangels AR, Patterson BH, Levander OA, Norkus EP, Taylor PR. Body weight and prior depletion a_ect plasma ascorbate levels attained on identical vitamin C intake: A controlled-diet study. J Am Coll Nutr. 1999 Dec;18(6):628-37.

53. Carr AC, Pullar JM, Bozonet SM, Vissers MC. Marginal ascorbate status (hypovitaminosis $\mathrm{C}$ ) results in an attenuated response to vitamin C supplementation. Nutrients. 2016 Jun 3;8(6):341. doi: 10.3390/nu8060341.

54. Hemila H. Vitamin $\mathrm{C}$ and the common cold. Br J Nutr. 1992;67(1):3-16. doi: 10.1079/BJN19920004.

55. Elwood PC, Lee HP, St Leger AS, Baird M, Howard AN. A randomized controlled trial of vitamin $\mathrm{C}$ in the prevention and amelioration of the common cold. Br J Prev Soc Med. 1976 Sep;30(3):193-6. doi: 10.1136/jech.30.3.193, PMID 788820.

56. Douglas RM, Hemila H, D'Souza R, Chalker EB, Treacy B. Vitamin $\mathrm{C}$ for preventing and treating the common cold. Cochrane Database Syst Rev. 2004 Oct;18(4):CD000980. doi: 10.1002/14651858.CD000980.pub2, PMID 15495002.

57. Campbell JD, Cole M, Bunditrutavorn B, Vella AT. Ascorbic Aacid is a potent inhibitor of various forms of T cell apoptosis. Cell Immunol. 1999 May 25;194(1):1-5. doi: 10.1006/cimm.1999.1485, PMID 10357874.

58. Wintergerst ES, Maggini S, Hornig DH. Immune-enhancing role of vitamin $C$ and zinc and effect on clinical conditions. Ann Nutr Metab. 2006;50(2):85-94. doi: 10.1159/000090495, PMID 16373990.

59. Bourne GH. The effect of vitamin $C$ on the healing of wounds. Proc Nutr Soc. 1946;4(3-4):204-16. doi: 10.1079/pns19460041, PMID 21002288.

60. Hellman L, Burns JJ. Metabolism of L-ascorbic acid-1-C14 in man. J Biol Chem. 1958 Feb;230(2):923-30. doi: 10.1016/S0021-9258(18)70515-2, PMID 13525409.

61. Jagetia GC, Rajanikant GK, Mallikarjun Rao KVN. Ascorbic acid increases healing of excision wounds of mice whole body exposed to different doses of gamma-radiation. Burns. 2007 Jun;33(4):484-94. doi: 10.1016/j.burns.2006.08.025, PMID 17223272.

62. Mathur V, Murdia A, Hakim AA, Suhalka ML, Shaktawat GS, Kothari LK. Male infertility and the present status of its management by drugs. J Postgrad Med. 1979 Apr;25(2):90-6. PMID 501675.

63. Chinoy NJ, Mehta RR, Seethalakshmi L, Sharma JD, Chinoy MR. Effects of vitamin C deficiency on physiology of male reproductive organs of guinea pigs. Int J Fertil. 1986 Aug;31(3):232-9. PMID 2875967.

64. Agarwal A, Nallella KP, Allamaneni SRS, Said TM. Role of antioxidants in treatment of male infertility: an overview of the literature. Reprod Biomed Online. 2004;8(6):616-27. doi: 10.1016/s1472-6483(10)61641-0, PMID 15169573.

65. Colagar AH, Marzony ET. Ascorbic acid in human seminal plasma: determination and its relationship to sperm quality. J Clin Biochem Nutr. 2009 Sep;45(2):144-9. doi: 10.3164/jcbn.08-251, PMID 19794921.

66. Saleh RA, Agarwal A, Nada EA, El-Tonsy MH, Sharma RK, Meyer A, Nelson DR, Thomas AJ. Negative effects of increased sperm DNA damage in relation to seminal oxidative stress in men with idiopathic and male factor infertility. Fertil Steril. 2003 Jun;79(3)Suppl 3:1597-605. doi: 10.1016/s00150282(03)00337-6, PMID 12801566.

67. Agarwal A, Ikemoto I, Loughlin KR. Relationship of sperm parameters with levels of reactive oxygen species in semen specimens. J Urol. 1994 Jul;152(1):107-10. doi: 10.1016/s0022-5347(17)32829-x, PMID 8201640.

68. Verma A, Kanwar KC. Human sperm motility and lipid peroxidation in different ascorbic acid concentrations: an in vitro analysis. Andrologia. 1998 Nov;30(6):325-9. doi: 10.1111/j.1439-0272.1998.tb01178.x, PMID 9835946.

69. Chambial S, Dwivedi S, Shukla KK, John PJ, Sharma P. Vitamin C in disease prevention and cure: an overview. Indian J Clin Biochem. 2013 Oct;28(4):314-28. doi: 10.1007/s12291-0130375-3, PMID 24426232.

70. Henmi H, Endo T, Kitajiima Y, Manase K, Hata H, Kudo R. Effects of ascorbic acid supplementation on serum progesterone levels in patients with a luteal phase defect. Fertil Steril. 2003 Aug;80(2):459-61. doi: 10.1016/s0015-0282(03)00657-5, PMID 12909517.

71. Cameron E, Campbell A. The orthomolecular treatment of cancer. II. Clinical trial of high-dose ascorbic acid supplements in advanced human cancer. Chem Biol Interact. 1974 Oct;9(4):285315. doi: 10.1016/0009-2797(74)90019-2, PMID 4430016.

72. Cameron E, Pauling L. Supplemental ascorbate in the supportive treatment of cancer: prolongation of survival times in terminal human cancer. Proc Natl Acad Sci USA. 1976 Oct;73(10):3685-9. doi: 10.1073/pnas.73.10.3685, PMID 1068480 .

73. Head KA. Ascorbic acid in the prevention and treatment of cancer. Altern Med Rev. 1998 Jun;3(3):174-86. PMID 9630735.

74. Block G. Vitamin C and cancer prevention: the epidemiologic evidence. Am J Clin Nutr. 1991 Jan;53(1)Suppl:270S-282S. doi: 10.1093/ajcn/53.1.270S, PMID 1985398.

75. Block G. Epidemiologic evidence regarding vitamin C and cancer. Am J Clin Nutr. 1991 Dec;54(6)Suppl:1310S-1314S. doi: 10.1093/ajcn/54.6.1310s, PMID 1962588.

76. Chen Q, Espey MG, Krishna MC, Mitchell JB, Corpe CP, Buettner GR, Shacter E, Levine M. Pharmacologic ascorbic acid concentrations selectively kill cancer cells: action as a pro-drug to deliver hydrogen peroxide to tissues. Proc Natl Acad Sci USA. 2005 Sep;102(38):13604-9. doi: 10.1073/pnas.0506390102, PMID 16157892.

77. Cabanillas F. Vitamin C and cancer: what can we conclude1,609 patients and 33 years later? P R Health Sci J. 2010 Sep;29(3):215-7. PMID 20799507.

78. Padayatty SJ, Riordan HD, Hewitt SM, Katz A, Hoffer LJ, Levine M. Intravenously administered vitamin $\mathrm{C}$ as cancer therapy: three cases. CMAJ. 2006;174(7):937-42. doi: 10.1503/cmaj.050346, PMID 16567755.

79. Kushi LH, Fee RM, Sellers TA, Zheng W, Folsom AR. Intake of vitamins A, C, and E and postmenopausal breast cancer. The Iowa Women's Health Study. Am J Epidemiol. 1996 Jul 15;144(2):16574. doi: 10.1093/oxfordjournals.aje.a008904, PMID 8678048.

80. Stohs SJ, Bagchi D. Oxidative mechanisms in the toxicity of metal ions. Free Radical Biol Med. 1995 Feb;18(2):321-36. doi: 10.1016/0891-5849(94)00159-h, PMID 7744317. 
81. Shaban El-Neweshy M, Said El-Sayed Y. Influence of vitamin C supplementation on lead-induced histopathological alterations in male rats. Exp Toxicol Pathol Exp Toxicol Pathol. 2011 Mar;63(3):221-7. doi: 10.1016/j.etp.2009.12.003, PMID 20056397.

82. Singh AL, Singh VK, Srivastava A. Effect of arsenic contaminated drinking water on human chromosome: a case study. Ind J Clin Biochem. 2013 Oct;28(4):422-5. doi: 10.1007/s12291-0130330-3.

83. Herrera A, Pineda J, Antonio MT. Toxic effects of perinatal arsenic exposure on the brain of developing rats and the beneficial role of natural antioxidants. Environ Toxicol Pharmacol. 2013 Jul;36(1):73-9. doi: 10.1016/j.etap.2013.03.018, PMID 23619517.

84. H El-Sokkary G. The protective role of vitamin c against cerebral and pulmonary damage induced by cadmium chloride in male adult albino rat. Toneuroej 2011;4(1):1-8. doi: 10.2174/1876528901104010001.

85. Gajawat S, Sancheti G, Goyal PK. Vitamin C against concomitant exposure to heavy metal and radiation: a study on variations in hepatic cellular counts. Asian J Exp Sci. 2005;19(2):53-8.

86. Wild S, Roglic G, Green A, Sicree R, King H. Global prevalence of diabetes: estimates for the year 2000 and projections for 2030. Diabetes Care. 2004 May;27(5):1047-53. doi: 10.2337/diacare.27.5.1047, PMID 15111519.

87. American Diabetes Association. Diagnosis and classification of diabetes mellitus. Diabetes Care. 2010 Jan;33(1):S62-S69.

88. Roösen P, Nawroth PP, King G, Moöller W, Tritschler HJ, Packer L. The role of oxidative stress in the onset and progression of diabetes and its complications: a summary of a Congress Series sponsored by UNESCO-MCBN, the American Diabetes Association and the German Diabetes Society. Diabetes Metab Res Rev. 2001;17(3):189-212. doi: 10.1002/dmrr.196, PMID 11424232.

89. Harding $\mathrm{AH}$, Wareham NJ, Bingham SA, Khaw K, Luben R, Welch A, Forouhi NG. Plasma vitamin C level, fruit and vegetable consumption, and the risk of new-onset type 2 diabetes mellitus: the European prospective investigation of cancer-Norfolk prospective study. Arch Intern Med.. 2008 Jul 28;168(14):1493-9. doi: 10.1001/archinte.168.14.1493, PMID 18663161.

90. Sridulyakul P, Wongeak-in N, Patumraj S. Correlations between endothelial functions and ROS detection in diabetic microvascular wall: early and late ascorbic acid supplementation. Int J Vasc Med. 2012;2012:709695:709695. doi: 10.1155/2012/709695.

91. Hoffman RP, Dye AS, Bauer JA. Ascorbic acid blocks hyperglycemic impairment of endothelial function in adolescents with type 1 diabetes. Pediatr Diabetes. 2012 Dec;13(8):607-610. doi: 10.1111/j.1399-5448.2012.00882.x, PMID 22925199.
92. Ziegler D, Sohr CG, Nourooz Zadeh J. Oxidative stress and antioxidant defense in relation to the severity of diabetic polyneuropathy and cardiovascular autonomic neuropathy. Diabetes Care. 2004 Sep;27(9):2178-83. doi: 10.2337/diacare.27.9.2178, PMID 15333481.

93. Singh PP, Mahadi F, Roy A, Sharma P. Reactive oxygen species, reactive nitrogen species and antioxidants in etiopathogenesis of diabetes mellitus type-2. Indian J Clin Biochem. 2009 Oct;24(4):324-42. doi: 10.1007/s12291-009-0062-6, PMID 23105858.

94. Rees DC, Kelsey H, Richards JMD. Acute haemolysis induced by high dose ascorbic acid in glucose-6-phosphate dehydrogenase deficiency. Br Med J. 1993 Mar 27;306(6881):841-2. doi: 10.1136/bmj.306.6881.841, PMID 8490379.

95. Bendich A. Safety issues regarding the use of vitamin supplements. Ann NY Acad Sci. 1992 Sep 30;669:300-31230010; discussion 311. doi: 10.1111/j.1749-6632.1992.tb17109.x, PMID 1444034

96. Hathcock IN. Safety of vitamin and mineral supplements. In: Micronutrients in Health and in disease prevention, cds. A Bendich. CE Butterworth Jr, New Yark: Dekker; 1991. p. 439-50.

97. Rivers JM. Safety of high-level vitamin c ingestion. Ann N Y Acad Sci. 1987;498(1 Third Confere):445-54. doi: 10.1111/j.1749-6632.1987.tb23780.x.

98. Schmidt KH, Hagmaier V, Horning DH, Vuilleumier JP, Rutishauser G. Urinary oxalate excretion after large intakes of ascorbic acid in man. Am J Clin Nutr. 1981 Mar;34(3):305-11. doi: 10.1093/ajcn/34.3.305, PMID 7211731.

99. Trinchieri A, Mandressi A, Luongo P, Longo G, Pisani E. The influence of diet on urinary risk factors for stones in healthy subjects and idiopathic renal calcium stone formers. Br J Urol. 1991 Mar;67(3):230-6. doi: 10.1111/j.1464410x.1991.tb15124.x, PMID 2021806.

100. Urivetzky M, Kessaris D, Smith AD. Ascorbic acid overdosing: a risk factor for calcium oxalate nephrolithiasis. J Urol. 1992 May;147(5):1215-8. doi: 10.1016/s0022-5347(17)37521-3, PMID 1569652.

101. Balcke P, Schmidt P, Zazgornik J, Kopsa H, Haubenstock A. Ascorbic acid aggravates secondary hyperoxalemia in patients on chronic hemodialysis. Ann Intern Med. 1984;101(3):344-5. doi: 10.7326/0003-4819-101-3-344, PMID 6465702.

102. Chalmers AUH, Cowley ODM, Brown JM. A possible etiological role for ascorbate in calculi formation. Clin Chem. 19861986 Feb;32(2):333-6. doi: 10.1093/clinchem/32.2.333, PMID 3943193.

103. Tomson CRV, Channon SM, Parkinson IS, McArdle PP, Qureshi M, Ward MK, Laker MF. Correction of subclinical ascorbate deficiency in patients receiving dialysis: effects on plasma oxalate, serum cholesterol, and capillary fragility. Clin Chim Acta. 1989;180(3):255-64. doi: 10.1016/00098981(89)90007-7, PMID 2743578. 